\title{
PELATIHAN PENULISAN CERITA PENDEK BERKEADILAN GENDER DI MADRASAH ALIYAH AL HIDAYAH KECAMATAN WAJAK KABUPATEN MALANG
}

\author{
Galuh Nur Rohmah, Laily Fitriani, Vita Nur Santi \\ Universitas Islam Negeri Maulana Malik Ibrahim Malang \\ E-mail: galuhnurrohmah@yahoo.com
}

\begin{abstract}
Practitioner and expert of education have also given idea about role of belleslettres in education of child character. Do not deny again that belleslettres of have important role in the world of education. Short story as one of belleslettres form in creative writing region can be made media to study of justice and equivalence of gender among adolescent as well as children. Adolescent in this time have recognized fiction readings in the form of short story, continued story, novel even pictorial story or comic. Meanwhile, not deny that a masterpiece, a story specially, not get out of its writer background. This research take location in Madrasah Aliyah Al Hidayah Countryside of Wajak, District Of Wajak, Malang. And result of from this research of change at student after is adjacent 1) student have information and knowledge about gender and his aspects 2) change of patterned thinking to treat fairly and equivalent between men and woman of that goodness at home, school, and environment, and 3) student can put down issue justice of gender in its short story.

Keyword: education, gender equity, short stories
\end{abstract}

\section{Abstrak}

Dewasa ini beberapa ahli dan praktisi pendidikan juga telah memberikan gagasan tentang peran karya sastra dalam pendidikan karakter anak. Tak dipungkiri lagi bahwa karya sastra memilki peran penting dalam dunia pendidikan. Cerita pendek sebagai salah satu bentuk karya sastra dalam wilayah kepenulisan kreatif bisa dijadikan media bagi pembelajaran keadilan dan kesetaraan gender di kalangan remaja dan juga anakanak. Remaja saat ini sudah mengenal bacaan-bacaan fiksi berupa cerita pendek, cerita bersambung, novel bahkan cerita bergambar atau komik. Sementara itu, tidak dipungkiri bahwa sebuah karya, sebuah cerita khususnya, tidak lepas dari latar belakang penulisnya. Penelitian ini mengambil lokasi di Madrasah Aliyah Al Hidayah Desa Wajak, Kecamatan Wajak, Kabupaten Malang sebagai lokusnya. Dan hasil dari penelitian ini adalahterjadi perubahan pada siswa setelah dilakukan pendampingan; 1) siswa memiliki pengetahuan dan informasi tentang gender dan aspek-aspeknya, 2) perubahan pola pikir untuk memperlakukan secara adil dan setara antara laki-laki dan perempuan baik itu di rumah, di sekolah, dan di lingkungan sekitar, dan 3) siswa mampu meletakkan isu keadilan gender dalam cerita pendeknya.

Kata Kunci: cerita pendek, berkeadilan gender, pendidikan

\section{Pendahuluan}

Usaha yang harus dilakukan untuk mencapai keadilan gender nampaknya bukan hanya sekedar bersifat individual, namun harus secara bersama dan bersifat institusional, utamanya dari pihak-pihak yang memiliki kewenangan kekuasaan dan memegang peran dalam proses pembentukan gender. Untuk itu peranan pembuat kebijakan dan perencanaan pembangunan menjadi sangat penting dan menentukan arah perubahan menuju kesetaraan gender atau dapat 
dikatakan bahwa negara atau pemerintah mempunyai peran/ andil dalam mewujudkan keseimbangan gender. Dalam setiap perencanaan pembangunan, gender hendaknya dijadikan sebagai "kata kunci" dalam memahami kegiatan apa yang dilakukan laki-laki dan perempuan?, Berapa banyak waktu yang diperlukan untuk kegiatan tersebut?, Siapa yang memutuskan? dan sebagainya.

Selain dalam realitas kehidupan nyata, ketidakadilan dan ketidaksetaraan gender juga direfleksikan dalam karya-karya sastra, baik itu sastra tulis maupun lisan (Eriyanto, 2001). Beberapa kajian sebelumnya yang mendiskusikan tentang ketidaksetaraan gender atau ketidakadilan gender dalam karya sastra masih menggunakan novel-novel popular dan kategori dewasa, misalnya Uli (2011), Wiguna (2011), Husna (2013). Sedangkan beberapa penelitian yang mengkaji novel-novel islami selama ini belum menyentuh topik gender, seperti Hakim (2010) dan Hariyanto (2008).

Dewasa ini beberapa ahli dan praktisi pendidikan juga telah memberikan gagasan tentang peran karya sastra dalam pendidikan karakter anak. Tak dipungkiri lagi bahwa karya sastra memilki peran penting dalam dunia pendidikan. Setidaknya ada sembilan peran yang diberikan (Haryadi, 1994), diantaranya (1) dapat berperan sebagai hiburan dan media pendidikan, (2) isinya dapat menumbuhkan kecintaan, kebanggaan berbangsa dan hormat pada leluhur, (3) isinya dapat memperluas wawasan tentang kepercayaan, adat-istiadat, dan peradaban bangsa, (4) pergelarannya dapat menumbuhkan rasa persatuan dan kesatuan, (5) proses penciptaannya menumbuhkan jiwa kreatif, responsif, dan dinamis, (6) sumber inspirasi bagi penciptaan bentuk seni yang lain, (7) proses penciptaannya merupakan contoh tentang cara kerja yang tekun, profesional, dan rendah hati, (8) pergelarannya memberikan teladan kerja sama yang kompak dan harmonis, (9) pengaruh asing yang ada di dalamnya memberi gambaran tentang tata pergaulan dan pandangan hidup yang luas.

Cerita pendek sebagai salah satu bentuk karya sastra dalam wilayah kepenulisan kreatif bisa dijadikan media bagi pembelajaran keadilan dan kesetaraan gender di kalangan remaja dan juga anak-anak. Remaja saat ini sudah mengenal bacaan-bacaan fiksi berupa cerita pendek, cerita bersambung, novel bahkan cerita bergambar atau komik. Sementara itu, tidak dipungkiri bahwa sebuah karya, sebuah cerita khususnya, tidak lepas dari latar belakang penulisnya, apalagi jika penulis adalah seorang muslim, besar kemungkinan kelahiran novel tersebut dilatarbelakangi oleh motivasinya untuk menyampaikan pesan moral yang terkandung dalam ajaran agamanya, yaitu peristiwa yang berlangsung atau yang dialaminya (Nurgiantoro, 1995: 322). Sehingga apa yang dinarasikan oleh penulis dalam sebuah cerita tentunya akan memberikan dampak kepada pembaca, termasuk pembaca remaja, yang tentunya bisa sangat terkesan dan menghayati sebuah cerita. Genre cerita remaja islami muncul pada akhir tahun 90 -an. Cerita jenis ini memiliki peminat yang banyak. Hal tersebut ditandai dengan semakin banyaknya penerbit yang menerbitkan novel sejenis.

Di samping itu, usia remaja merupakan fase pencarian jati diri manusia, di mana karakter dan kepribadian seseorang akan bisa dibentuk dan diarahkan di usia tersebut. Sementara, kurikulum dan materi pelajaran di sekolah pada umumnya belum menyentuh ranah gender, sehingga dalam proses pembentukan karakter yang dilakukan di sekolah perlu disertakan nilai-nilai yang tidak biasa gender, atau biasa dikenal dengan pendidikan berkeadilan gender. Maraknya cerita remaja islami sebagai bahan bacaan para remaja dewasa ini, serta pentingnya pendidikan dan bekal pemahaman bagi remaja tentang kesetaraan dan keadilan gender, mendorong peneliti untuk melakukan pendampingan sekaligus pelatihan penulisan cerita pendek yang tidak bias gender di kalangan remaja dengan mengambil lokasi sekolah, di Madrasah Aliyah Al Hidayah Wajak, Kabupaten Malang.

Madrasah Aliyah (MA) Al Hidayah berlokasi di Jl. Lawu Desa Wajak, Kecamatan Wajak, Kabupaten Malang, yang merupakan wilayah Kabupaten Malang di sebelah timur. Jumlah siswa yang belajar di sekolah ini seluruhnya berjumlah sekitar 250 siswa dengan rata- 
rata jumlah siswa per kelas antara 25-30 siswa dari kelas X-XII. Masyarakat di kecamatan Wajak ini mayoritas bekerja di bidang pertanian dan perdagangan, sehingga latar belakang keluarga siswa di MA Al Hidayah bukanlah dari golongan menengah ke atas melainkan dari masyarakat ekonomi menengah ke bawah. Hal tersebut berdampak pada akses terhadap kemajuan teknologi pendidikan dan fasilitas pendidikan yang memadai masih kurang terpenuhi.

Sementara itu, fasilitas perpustakan yang ada di sekolah juga jauh dari kategori memadai untuk pengembangan minat dan bakat siswa dalam bidang baca tulis karya sastra. Kegiatan ektra kurikuler dan pembinaan minat dan bakat siswa masih berkisar di bidang olahraga dan seni. Sementara, bidang kepenulisan baik ilmiah ataupun sastra, dan atau jurnalistik belum ada. MA Al Hidayah juga termasuk sekolah pinggiran yang jarang sekali mendapat perhatian ataupun bantuan dari pemerintah ataupun lembaga pendidikan tinggi di Malang. Sehingga, tim peneliti tergerak untuk memberikan pendampingan di sekolah ini, dengan menggabungkan visi misi pendidikan gender dan teori kepenulisan cerita pendek.

Siswa di MA Al Hidayah kebanyakan memiliki latar belakang keluarga yang kurang perhatian terhadap pendidikan dan pengembangan potensi anak. Orang tua siswa yang mayoritas berasal dari ekonomi kelas bawah hanya berharap anak-anak mereka mendapat pendidikan dan menjadi orang baik nantinya. Mereka tidak mengetahui dan memahami bagaimana mereka harus mengembangkan potensi dan kelebihan yang dimiliki anak-anak mereka. Bahkan, mayoritas orang tua tidak mengenali bakat dan potensi atau kelebihan anakanak mereka yang semestinya dikembangkan.

Program pelatihan dan pendampingan yang akan diberikan kepada siswa-siswi MA Al Hidayah akan difokuskan untuk siswa/I kelas XI yang semuanya berjumlah 78 orang. Hal ini dilakukan dengan pertimbangan bahwa siswa/I kelas XII harus fokus pada persiapan ujian kelulusan, sedangkan kelas X mungkin masih relatif baru di sekolah dan dalam tahap adaptasi. Dari observasi dan penyebaran angket yang tim peneliti lakukan, diketahui bahwa ada sekitar 25 siswa/I kelas XI yang memiliki minat di bidang kepenulisan sastra, khususnya cerita pendek.

Dari 25 siswa/i tersebut, mayoritas sudah pernah menulis sebuah cerita, meskipun sebagai hobi ataupun karena tugas dari guru di sekolah. Cerita yang digemari antara lain cerita romantis dan percintaan, cerita sejarah, cerita inspiratif dan cerita-cerita lain yang memotivasi dan memberikan pelajaran terhadap mereka setelah membacanya. Diantara mereka ini, ratarata menyukai dan sering membaca karya sastra, akan tetapi mereka belum mendapatkan akses yang mudah dan terjangkau terhadap sumber-sumber yang diperlukan. Seperti yang disebutkan sebelumnya, bahwa perpustakaan sekolah masih jauh dari kategori memadai dalam menyediakan sumber-sumber bacaan yang diperlukan siswa untuk mengembangakan minat dan bakat dalam bidang baca tulis sastra.

Masalah yang menjadi fokus pendampingan ini adalah "Bagaimana pelatihan penulisan cerita pendek berkeadilan gender meningkatkan pengetahuan keadilan gender dan kemampuan menulis cerita pendek berkeadilan gender siswa MA Al Hidayah?'. Setelah program pendampingan ini dilakukan, maka diharapkan remaja di MA Al-Hidayah, khususnya yang meminati penulisan karya sastra dapat menulis cerpen yang berkeadilan gender. Oleh karena itu, dapat diuraikan bahwa kondisi dampingan yang diharapkan setelah pelaksanaan program penelitian PAR ini adalah sebagai berikut:

1. Terbangunnya pemahaman dan kesadaran yang berkeadilan gender dalam menulis karya sastra (cerpen).

2. Meningkatnya pengembangan kemampuan menulis yang berkeadilan gender.

3. Terciptanya kehidupan sosial yang harmoni antara laki-laki dan perempuan.

\section{Metode}


Dalam rangka mengubah pemahaman remaja tentang kesetaraan gender, akan digunakan metode PAR (Parcipatory Action Research). Metode ini dilakukan untuk memahamkan remaja MA Al-Hidayah terhadap: a) kelemahan-kelemahan yang dihadapi dan dimilikinya; 2) keinginan-keinginan remaja untuk mengatasi kekurangan dan kelemahannya; c) menyusun strategi dan metode untuk memecahkan permasalahannya; d) membantu remaja mengatasi, memecahkan dan menemukan jalan keluarnya.

Metode PAR ini digunakan untuk tidak membuat masyarakat dampingan sebagai obyek, tetapi menjadikannya sebagai subyek penelitian. Remaja MA Al-Hidayah sendiri yang memahami, menginginkan, dan memecahkan permasalahan yang dihadapinya. Posisi peneliti lebih sebagai fasilitator bagi Remaja MA Al-Hidayah serta memberikan jalan keluar dan merumuskan strategi yang dapat digunakan untuk mencari solusi bagi permasalahan mereka. Namun perumusan jalan keluar dan strategi ini tetap melibatkan para remaja MA Al-Hidayah dengan harapan setelah pelatihan ini selesai dapat terus berkarya dengan menulis karya sastra yang berkeadilan gender.

Dengan Parsipatory Action Research (PAR) ini bermanfaat untuk memfasilitasi dan memotivasi agar masyarakat khususnya kalangan remaja mampu: 1) Mengidentifikasi kekuatan dan kelemahan remaja serta problemantikanya dalam kehidupan yang berkeadilan gender, 2) Menemukenali faktor penyebab problem remaja yang tidak berkeadilan gender dan alternatif solusinya, 3) Menyusun strategi dan metode yang tepat untuk memecahkan permasalahan remaja, dan 4) Menyusun rencana aksi berdasarkan prioritas dan keberlanjutan program melalui tahapan-tahapan hingga mencapai target yang diharapkan.

Adapun strategi yang digunakan dalam melakukan action research ini adalah menggunakan metode yang dikemukakn oleh Kurt Lewin dalam Arikunto (2006: 92) didasarkan atas konsep pokok bahwa penelitian tindakan yang terdiri empat komponen pokok yang juga menunjukkan langkah, yaitu: a) perencanaan atau planning yang dilakukan setelah memperhatikan kondisi riil di masyarakat dengan menggunakan analisis SWOT. Dalam menganalisis problemantika menulis di kalangan remaja sekolah dan menganalisis kekuatan, kelemahan, peluang dan ancaman yang mungkin terjadi. Hal ini dilakukan dengan melibatkan remaja di Madrasah Aliyah Al-Hidayah Wajak Kabupaten Malang. Perencanaan ini meliputi strategi dan metode dalam memecahkan problemantika tentang pemahaman gender bagi remaja di tingkat sekolah menengah, b) tindakan atau acting yang dilakukan dengan cara para remaja di MA al-Hidayah mengimplementasikan rencana yang telah dibuat tersebut dengan dibantu dan difasilitatori oleh peneliti, c) pengamatan atau observing yang dilakukan untuk memperhatikan dan menganalisis keberhasilan, kelemahan, dan kekurangan strategi dan metode yang digunakan dalam menyelesaikan problemantika yang terjadi di masyarakat.dan d) refleksi atau reflecting terhadap usaha-usaha yang dilakukan dalam memecahkan problemantika remaja di sekolah tersebut direfleksikan dan dievaluasi, baik kekurangan, kelemahan dan keberhasilan strategi dan metode dalam memecahkan problemantika remaja tersebut. Refleksi dan evaluasi ini berujung pada perencanaan (plan) seperti pada poin pertama untuk menuntaskan problem yang dihadapi remaja, baik yang belum tuntas pada tahap pertama atau untuk memecahkan problemantika yang baru hingga tercapai remaja di tingkat sekolah menengah yang pro kesetaraan gender dalam menulis karya sastra.

Pihak-pihak (stakeholder) yang terlibat dalam program pendampingan ini adalah

Tim Peneliti Pengumpul data dengan cara pembagian kuesioner tentang bakat dan minat, dan FGD. Pembuat desain aksi berdasarkan data yang diperoleh dan melalui koordinasi intensif berkala. Pelaksana pelatihan workshop wawasan gender dan penulisan kreatif. Para tim peneliti akan mempersiapkan materi dan menentukan teknis pelaksanaan berkoordinasi dengan pihak sekolah untuk menentukan strategi dan waktu pelaksanaan. Pelaksana monitoring dan evaluasi tiap kegiatan dengan menyediakan lembar evaluasi untuk siswa dan pihak sekolah serta evaluasi diri tentang aspek-aspek yang sudah berjalan lancar maupun 
kendala yang dihadapi. Pembuat desain tindak lanjut sebagai bahan untuk melakukan tahap kegiatan selanjutnya sehingga sesuai dengan tujuan dan kebutuhan di lapangan. Siswa Madrasah Aliyah. Pada tahap awal workshop wawasan gender mereka akan dilibatkan semua, kemudian dilakukan penjaringan bakat minat untuk memilih 20 siswa yang berbakat dan berminat tinggi untuk penulisan cerita pendek. Siswa yang terlibat adalah kelas 2, laki-laki dan perempuan. Dalam penulisan cerita pendek, mereka akan dipasangkan sehingga relasi gender dapat teraplikasikan sejak dari awal. Siswa akan terlibat sebagai: pelaksana desain program aksi dan pelaksana aksi kesetaraan gender. Kepala Sekolah dan Guru Bahasa Indonesia. Kedua pihak akan menjadi patner dalam bekerjasama dan berkoordinasi tentang teknis pelaksanaan aksi sehingga dapat berjalan sesuai rencana dan dapat mencapai tujuan. Keterlibatan kedua pihak sebagai: pendamping pelaksana desain aksi, pelaksana evaluasi dan monitoring tentang kesetaraan gender di kalangan remaja dan penyedia informasi tentang kondisi dan situasi tempat pelaksanaan aksi

\section{Proses Pendampingan}

Proses pendampingan terdiri dari dua tahap, perencanaan pendampingan dan pelaksanaan kegiatan pendampingan. Terdapat pula pembahasan tentang kendala yang dihadapi dan strategi untuk mengatasinya. Perencanaan dalam program PAR ini disusun secara partisipatif dengan melibatkan siswa dan stakeholder setelah terlebih dahulu dilakukan survey analisa kebutuhan sehingga kegiatan ini diharapkan sesuai dengan kebutuhan strategis siswa. Perencanaan diawali dengan penjaringan peserta melalui penyebaran angket pada siswa kelas. Angket berisi pertanyaan-pertanyaan yang meliputi informasi awal tentang wawasan dan minat baca karya sastra, pengetahuan tentang ciri-ciri karya sastra yang baik, prediksi tren karya sastra, pengalaman menulis karya sastra, dan kesediaan mengikuti pendampingan. Adapun hasil asesmen lapangan terhadap para siswa ditemukan ada 30 dari 70 siswa berminat menjadi peserta workshop penulisan cerpen Perencanaan dilanjutkan dengan diskusi bersama Wakil Kepala sekolah bidang Kesiswaan dan guru Bahasa Indonesia terkait kegiatan minat bakat siswa dalam hal penulisan kreatif, khususnya cerita pendek.

Pendampingan bersifat pemberdayaan kapasitas diri agar siswa memiliki pola pikir keadilan gender dalam kehidupan sehari-harinya, peneliti berfungsi sebagai fasilitator dan motivator dalam mengantarkan mereka menjadi individu yang memahami dan melaksanakan keadilan gender. Dalam merencanakan rencana aksi hingga menjadi jadual kegiatan pemberdayaan ini, peneliti bersama stakeholder dan siswa mendiskusikan kemungkinan hambatan-hambatan yang muncul pada saat pelaksanaan kegiatan sehingga telah diantisipasi sejak awal solusi yang dipilih. Pertimbangan dan input yang bermanfaat untuk kelancaran kegiatan pendampingan juga diberikan oleh pihat terkait dari sekolah.

Berdasarkan hasil FGD dan penjaringan, secara bersama-sama antara siswa, peneliti, dan stakeholder menyusun kegiatan menjadi beberapa siklus. Siklus 1 meliputi workshop pengenalan/sosialisasi gender (Zuhriyah, 2014) dan workshop penulisan cerita pendek. Siklus ini bertujuan memberikan penguatan tentang pentingnya pengetahuan bagaimana lakilaki dan perempuan berelasi dalam konteks sosial dan budaya. Siklus 2 adalah pembuatan kerangka cerpen berbasis keadilan gender yang bertujuan untuk membekali remaja tentang teknis penulisan cerpen yang berorientasi pada kesetaraan gender (Tarigan, 2010). Siklus 3 meliputi umpan balik, penulisan cerita pendek dan rencana tindak lanjut yang bertujuan untuk mengekspresikan ide dalam bentuk karya sastra yang berkeadilan gender.

Hasil evaluasi dan refleksi pada siklus lini adalah: a) Siswa mampu memahami konsep dasar tentang perbedaan biologis dan non-biologis antara laki-laki dan perempuan, b) Siswa mampu mengidentifikasi dan memberi contoh konkrit perbedaan non-biologis sesuai dengan situasi mereka, c). Siswa mampu memberikan pandangannya terhadap tugas-tugas dan peran sosial yang dapat berlaku bagi laki-laki dan perempuan, dan d) Siswa memperoleh 
pengetahuan bahwa karya sastra juga menjadi wadah untuk memunculkan isu-isu gender, e) Siswa mengetahui langkah-langkah penulisan karya sastra.

Hasil evaluasi dan refleksi pada siklus 2 ini adalah: a) Siswa mampu menganalisa isi cerita pendek yang mengandung isu-isu gender yang meliputi pelabelan, kata-kata dan kalimat-kalimat yang memojokkan, dan penggabaran peran antara laki-laki dan perempuan yang tidak seimbang(Daniel, 2004), b) Siswa memahami elemen-elemen dalam cerita pendek, dan bagaimana mengembangkan sebuah cerita yang mengandung keadilan gender, c) Siswa mampu berinteraksi dengan temannya, dan menegosiasikan ide-ide menjadi sebuah kesepakatan, dan d) Siswa mampu menghasilkan kerangka karangan yang siap dikembangan menjadi cerpen berbasis keadilan gender.

Hasil evaluasi dan refleksi pada siklus 3 adalah: a) Siswa mampu menghasilkan cerita pendek yang menggambarkan adanya relasi laki-laki dan perempuan, b) Ketika melakukan self-assessment, siswa mendapatkan kesempatan untuk menilai kekurangan dalam cerita pendeknya, dan mampu mengidentifikasi aspek-aspek apa saja yang butuh dikembangkan agar cerpennya memiliki kriteria cerpen yang berbasis kesetaraan gender, dan c) Siswa memiliki motivasi yang tinggi untuk menyelesaikan dan merevisi cerpennya karena cerpen akan diterbitkan dan dipilih tiga terbaik.

Dalam melaksanakan proses pendampingan, sudah barang tentu tidak terlepas dari beberapa kendala berikut: Pertama, Kesulitan koordinasi dengan stakeholder. Hal ini disebabkan jarak lokasi pendampingan yang cukup jauh dan kesibukan masing-masing pihak sehingga proses komunikasi dan diskusi perencanaan dan kegiatan pendampingan tidak dapat didiskusikan dengan maksimal. Selain itu, kendala ini juga bisa menyebabkan pemahaman mengenai program pembinaan yang diperoleh Kepala Sekolah dan guru pembina kurang komprehensif. Kedua, Berkurangnya minat siswa. Meskipun peserta pendampingan adalah siswa yang sudah melalui proses penjaringan akan tetapi jika dilihat dari jumlah dari siklus per siklus ada penurunan jumah peserta meskipun tidak signifikan. Ada beberapa kemungkinan yang menyebabkan beberapa siswa tidak dapat mengikuti pembinaan, yaitu, waktu pembinaan yang diadakan setelah pulang sekolah pukul 14.00 yang biasanya kurang kondusif untuk melakukan aktifitas yang menuntut mereka untuk berfikir, beberapa siswa tinggal di pondok pesantren sehingga tidak bisa leluasa untuk tetap di sekolah karena ada kegiatan pondok yang harus diikuti, dan kegiatan ekstra kurikuler seperti pramuka dan les mata pelajar.

Ketiga, Ketersediaan akses sumber bacaan terbatas. Belum tersedianya tempat sumber belajar seperti perpustakaan di madrasah Al Hidayah sehingga kebutuhan siswa untuk meningkatkan minat membaca karya sastra belum terpenuhi. Sebenarnya ada akses internet yang memudahkan siswa untuk mencari sumber bacaan, tetapi hanya terbatas penggunaannya ketika mereka di sekolah. Jika berbentuk buku yang dapat dipinjam dari perpustakaan tentunya siswa lebih fleksibel di manapun dan kapanpun mereka ingin membacanya. Keempat, Kegiatan Tindaklanjut. Setelah kegiatan pendampingan berakhir, para siswa sebagai subyek pendampingan kesulitan melakukan tindak lanjut dari pelatihan. Ada sebagian yang menulis cerita pendek hanya sebagai gugur kewajiban untuk memenuhi tugas kegiatan pendampingan. Dan ada sebagain lagi tidak melakukan dengan serius ketika merevisi cerpennya. Untuk kegiatan tindaklanjut, siswa masih belum bisa secara mandiri menginisiasi gerakan cinta karya sastra dan menulis cerita pendek. Keterbatasan SDM guru pembina dan ketersediaan waktu pembinaan menjadi kendala tindaklanjut kegiatan sehingga dikuatirkan keberlanjutan program pembinaan tidak dapat dicapai.

Untuk mengatasi beberapa kendala yang ada, peneliti telah mengupayakan strategi untuk mengatasinya sebagaimana berikut: 1) peneliti memaksimalkan penggunaan HP untuk komunikasi agar kegiatan tidak mengalami penundaan. Peneliti lebih mengedepankan komunikasi personal dengan salah satu guru untuk mengkomunikasikan program 
pendampingan kepada Kepala Sekolah. Di samping itu peneliti mengoptimalkan peran dan fungsi koordinator siswa yang bertanggungjawab selama PAR ini berlangsung untuk mengkondisikan kegiatan pelatihan dan koordinasi antar remaja dalam proses pendampingan, 2) mempermudah sistem permohonan ijin kepada pihak pondok dan pembina ekstrakurikuler yang dilakukan oleh peneliti dengan persetujuan pihak sekolah. Untuk mengatasi menurunnya semangat siswa ketika pembinaan di kelas, peneliti berusaha menyajikan materi dengan pola interaktf dengan melibatkan siswa secara aktif dalam diskusi. Siswa diposisikan sebagai subjek yang memiliki pengetahuan dan ide untuk dibagi. Siswa juga diberi otoritas penuh dalam menentukan topik cerpen dan alur ceritanya.

Strategi yang tak kalah pentingnya adalah pemberian motivasi untuk belajar bersamasama dengan prinsip No Child Left Behind yang artinya tidak ada seorangpun yang tertinggal. Membangun kesamaan persepsi dalam mewujudkan cerpen berbasis kesetaraan gender selalu menjadi poin utama yang ditekankan pada setiap siklusnya. Strategi ketiga adalah memberikan fotokopi contoh cerpen untuk dibaca dan dianalisa bersama. Contoh cerpen diambil dari salah satu kumpulan cerpen yang diterbitkan oleh penerbit yang kredibel sehingga siswa mendapatkan rangsangan yang dapat menstimulasi keinginan mereka untuk menulis cerita pendek yang berkualitas. Upaya tersebut dilanjutkan dengan pembelian kumpulan cerita pendek oleh peneliti untuk dibaca pada siklus 3 yang nantinya buku kumpulan cerpen tersebut disumbangkan kepada pihak sekolah agar siswa lainnya yang tidak ikut pembinaan dapat membacanya. Untuk menciptakan keberlanjutan program, peneliti memiliki beberapa strategi (startegi 4) yaitu strategi jangka pendek dalam bentuk penerbitan kumpulan cerita pendek yang ditulis siswa dan telah mengalami proses review dan revisi yang intensif. Penerbitan kumpulan cerita pendek para siswa menjadi produk akhir program ini, dan nantinya terbitan tersebut akan dimiliki masing-masing siswa dan sekolah untuk diakses siswa lain. Strategi jangka pendek yang mengiringi penerbitan cerita pendek adalah pemilihan tiga cerita pendek terbaik. Hal ini dapat memotivasi siswa untuk menulis karya terbaik.

\section{Perubahan Dan Hasil Pelatihan}

Perubahan yang terjadi pada siswa setelah kegiatan pendampingan dapat terlihat dari masing-masing siklus. Secara garis besar, perubahan yang terlihat dari siklus 1 dapat dijabarkan dalam 2 aspek. Perubahan pada aspek pengenalan gender yaitu: 1) Memahami perbedaan gender dalam ucapan dan tindakan, 2) Mengidentifikasi persoalan gender yang sering terjadi di masyarakat, baik dalam lingkup keluarga, sekolah dan masyarakat, 3) Berbagi pengalaman tentang bias gender yang pernah mereka dapatkan dari keluarga, sekolah dan masyarakat dalam bentuk perkataan dan perbuatan, 4) Memecahkan masalah yang terkait dengan gender di masyarakat dengan solusi-solusi yang telah mereka pahami, bagaimana menyikapi persoalan gender di masyarakat, 5) Memahami bahwa gender bisa muncul dalam ucapan dan perilaku, sehingga siswa dapat mengantisipasinya, dan 6) Mengupayakan untuk netral gender dalam berperilaku pada sesama. Perubahan pada penulisan cerita pendek, yaitu: 1) Memahami model karya sastra yang pro gender, netral gender dan bias gender (Fakih, 2008), 2) Terbangunnya kesadaran bahwa gender muncul di segala aspek dan tahu cara mengolah bahasa agar tidak bias gender melalui tokoh-tokoh cerita, dan 3) Mampu menciptakan karya sastra yang berkeadilan gender.

Perubahan yang terjadi pada siklus 2 adalah: 1) Mampu melakukan curah pendapat bersama teman untuk mencapai mufakat, 2) Memahami model pemaparan cerita berkeadilan gender, 3) Mengangkat berbagai isu dalam cerpen sesuai dengan realitas siswa, 4) Menggambarkan tokoh-tokoh sesuai dengan porsinya. Siklus 3 terjadi perubahan sebagai berikut: 1)Terbangunnya pemahaman yang konstruktif tentang model cerpen berkeadilan gender, 2) Memahami cara menciptakan konflik isi cerita, 3) Menulis cerita pendek 
berkeadilan gender, 4) Melakukan penilaian sendiri pada karya yang dihasilkan, dan 5) Dapat menerbitkan kumpulan cerita pendek.

\section{Penutup}

Dalam analisis gender terdapat kaitan erat antara perbedaan gender (gender differences) dan ketidakadilan gender (gender inequality) dengan struktur masyarakat yang luas. Gender sebagai pandangan hidup dalam kelompok masyarakat membedakan peran, fungsi dan tanggung jawab antara laki-laki dan perempuan. Memahami persoalan gender pada tataran remaja cukup menarik untuk diteliti. Penelitian yang memfokuskan pada gender di kalangan remaja setidaknya harus memberikan wawasan yang utuh tentang konsep gender itu sendiri, sehingga terbangun paradigma berpikir remaja yang berkeadilan gender. Persoalan gender di masyarakat berada pada berbagai lini kehidupan, baik itu dalam lingkup keluarga, sekolah, dan masyarakat.

Menulis sebagai bagian dari kegiatan literasi sangat penting dibangun sejak dini. Remaja sekolah sebagai generasi penerus bangsa perlu membekali diri dengan kemampuan literasi ini. Cerita sebagai media yang cukup digemari remaja memiliki peran penting untuk turut mensosialisasikan nilai-nilai moral. Menulis cerita juga suatu upaya untuk mengembangkan dan menggali kreativitas remaja dengan menyampaikan cerita berdasarkan fenomena yang terjadi di sekitar mereka, mulai dunia persahabatan, percintaan, kasih sayang, amarah, persaudaraan hingga persoalan politik. Oleh karena itulah, gender dapat disosialisasikan melalui media cerpen, sehingga persoalan gender dapat disederhanakan, mudah dipahami sesuai dengan usia remaja.

Dalam rangka mengubah pola pikir remaja yang responsif dan berkeadilan gender, maka digunakanlah metode PAR (Participatory Action Research). Metode ini diharapkan bisa bermanfaat untuk memfasilitasi dan memotivasi agar remaja mampu menemukenali model ucapan (dialog) serta perilaku yang bias gender, serta menemukan metode yang tepat untuk meemecahkan persoalan bias gender melalui menulis cerpen. Kegiatan ini melalui tahapan siklus yang dimulai dari perencanaan, pelaksanaan, pengamatan, dan refleksi yang diimplementasikan pada subyek dampingan remaja sekolah di MA. Al-Hidayah. Adapun hasil perubahan yang terjadi pada diri subyek dampingan adalah sebagai berikut: 1) Memahami perbedaan laki-laki dan perempuan secara biologis dan non biologis, 2) Mampu mengidentifikasi persoalan gender yang sering terjadi di masyarakat, baik dalam lingkup keluarga, sekolah dan masyarakat, dan 3) Menulis cerpen berkelompok berkeadilan gender.

\section{Rekomendasi}

Berdasarkan hasil pendampingan pelatihan kepenulisan berkeadilan gender di Madrasah Aliyah Al-Hidayah Wajak perlu direkomendasikan sebagai berikut:

1. Pemerintah perlu mensosialisasikan pendidikan berkeadilan gender kepada remaja sedini mungkin melalui gerakan literasi sehingga dapat memberikan wawasan baru dalam pendidikan gender.

2. Pihak sekolah perlu memberikan dukungan dalam pendidikan gender sehingga remaja sekolah lebih sadar gender, berkeadilan gender dalam tingkah laku serta ucapannya.

3. Peneliti perlu mengupdate berbagai model pendidikian berkeadilan gender untuk remaja melalui gerakan literasi selain menulis.

\section{Daftar pustaka}

Daniel, A.P. 2004. Medali. Kumpulan 'Kupu-kupu Tak Berkelopak” (Kumpulan Cerpen Pengarang). PT Gramedia. 
Eriyanto. 2001. Analisis Wacana: Pengantar Analisis Teks Media. Yogyakarta: LKIS

Fakih, Mansour. 2008. Analisis Gender dan Transformasi Sosial. Yogyakarta: Pustaka Pelajar.

Hakim, L. 2010. Conservative Islam Turn or Popular Islam? An Analysis of the Film AyatAyat Cinta. Al Jami'ah, Vol 48 (1), hal. 101-128

Hariyanto. 2008. Aspek Kepribadian Tokoh Raihana dalam Novel Pudarnya Pesona Cleopatra karya Habiburrahman El Shirazy dan Skenarion Pembelajrannya di Kelas XI SMA. Fakultas Keguruan dan Ilmu Pendidikan

Haryadi. 1994. Sastra Melayu. Yogyakarta: IKIP Yogyakarta.

Husna, N. 2013. Ketidaksetaraan Gender dalam Novel Perempuan Jogja Karya Achmad Munif: Tinjaun Sastra Feminis. Skripsi. Surakarta: FKIP UMS

Nurgiantoro, B. 1995. Teori Pengkajian Fiksi. Jogjakarta: UGM Press.

Tarigan, H. G. 2010. Prinsip-prinsip Dasar Sastra. Bandung: Angkasa.

Uli, I. 2011. Citra Perempuan dalam Novel Ratu Kecantikan Harga Sebuah Martabat karya Langit Kresna Hariadi. Skripsi. Pontianak: FKIP UNTAN.

Wiguna, S.C. 2011. Analisis Ketidakadilan Gender dalam Novel Sangn Maharani karya Agnes Jessica. Skripsi. Jember: Fakultas Sastra Universitas Jember.

Zuhriyah, E. 2014. Gender Sebagai Konstruksi Sosial. Makalah disampaikan pada Workshop Penguatan PUG Bidang Pendidikan Islam Melalui Penelitian di PSGA UIN Maulana Malik Ibrahim Malang.

(http://www.republika.co.id) diakses pada tanggal 25 Agustus 2015.

(http://www.academia.edu). diakses pada tanggal 25 Agustus 2015.

Arikunto, Suharsimi. 2006. Prosedur Penelitian Suatu Pendekatan Praktik. Jakarta: PT. Rineka Cipta.

Hakim, L. 2010. Conservative Islam Turn or Popular Islam? An Analysis of the Film AyatAyat Cinta. Al Jami'ah, Vol 48 (1), hal. 101-128

Hariyanto. 2008. Aspek Kepribadian Tokoh Raihana dalam Novel Pudarnya Pesona Cleopatra karya Habiburrahman El Shirazy dan Skenarion Pembelajrannya di Kelas XI SMA. Fakultas Keguruan dan Ilmu Pendidikan

Haryadi. 1994. Sastra Melayu. Yogyakarta: IKIP Yogyakarta.

Husna, N. 2013. Ketidaksetaraan Gender dalam Novel Perempuan Jogja Karya Achmad Munif: Tinjaun Sastra Feminis. Skripsi. Surakarta: FKIP UMS 
Nurgiantoro, B. 1995. Teori Pengkajian Fiksi. Jogjakarta: UGM Press.

Uli, I. 2011. Citra Perempuan dalam Novel Ratu Kecantikan Harga Sebuah Martabat karya Langit Kresna Hariadi. Skripsi. Pontianak: FKIP UNTAN.

Wiguna, S.C. 2011. Analisis Ketidakadilan Gender dalam Novel Sangn Maharani karya Agnes Jessica. Skripsi. Jember: Fakultas Sastra Universitas Jember.

Yoedo, Y.C. 2008. Women in Two Frames. Makalah disajikan dalam Seminar Internasional Dua Hari "Women in Public Sector", 16-17 Juli 2008 di Universitas Gajah Mada, Yogyakarta. 